\title{
One-pot three-component synthesis of new triazolopyrimidine derivatives bearing indole moiety as antiproliferative agents
}

\author{
Mohamed A. A. Radwan ${ }^{1,2^{*}}$, Fahad M. Alminderej ${ }^{1}$, Hala E. M. Tolan ${ }^{3}$, Hanem M. Awad $^{4}$ \\ ${ }^{1}$ Department of Chemistry, College of Science, Qassim University, Buraydah, Kingdom of Saudi Arabia. \\ ${ }^{2}$ Applied Organic Chemistry Department, National Research Center, Dokki, 12622, Egypt. \\ ${ }^{3}$ Department of Photochemistry, National Research Centre, Dokki, 12622, Cairo, Egypt. \\ ${ }^{4}$ Tanning Materials and Leather Technology Department, National Research Centre, Dokki, Cairo, 12311, Egypt.
}

\begin{tabular}{l}
\hline ARTICLE INFO \\
\hline Received on: $28 / 03 / 2020$ \\
Accepted on: $18 / 07 / 2020$ \\
Available online: 05/09/2020 \\
\\
\hline Key words: \\
Triazole, pyrimidine, indole, \\
multicomponent reaction, \\
antiproliferative.
\end{tabular}

\begin{tabular}{l}
\hline ABSTRACT \\
\hline A new series of triazolopyrimidine derivatives was produced via three-component reactions of suitable aromatic or \\
heteroaromatic carboxaldehyde, 3-amino-1,2,4-triazole, and 3-indolyl-3-oxopropanenitrile in triethylamine as a catalyst. \\
The new compounds have been interpreted using elemental analysis, infrared, mass spectrometry, and nuclear magnetic \\
resonance spectroscopy. Antiproliferative effects of the new compounds have been screened on four human cancer types and \\
one human noncancerous type (retinal pigment ephitilial-1) via the 3-(4,5-Dimethylthiazol-2-yl)-2,5-Diphenyltetrazolium \\
Bromide assay. Compounds $\mathbf{4 a}$ and $\mathbf{4 h}$ have moderate activity against the human colon cancer; most of the compounds \\
were active toward human lung cancer; compounds $\mathbf{4 i}, \mathbf{4 h}$, and $\mathbf{4 g}$ were highly active on hormone-dependent human breast \\
cancer, while compounds $\mathbf{4 c}, \mathbf{4 b}, \mathbf{4 h}$, and $\mathbf{4 e}$ were the most active on the hormone-independent human breast. The results \\
of this study offer a source for further investigation of selected triazolopyrimidine derivatives as antiproliferative agents.
\end{tabular}

\section{INTRODUCTION}

The construction of both scaffolds triazole and pyrimidine rings with a built-in indole moiety might have promising biological activity. Multicomponent reactions (MCRs) are a wide range of synthetic techniques that can be used to achieve this target candidate (Cioc et al., 2014; Dekamin et al., 2013; Liu et al., 2016; Peng et al., 2017; Ravichandiran et al., 2017; Rotstein et al., 2014). Compared to the direct synthesis method, the MCR method is appreciated for its cost-effectiveness, ease of set-up, and high production. Currently, many nitrogen heterocyclic structures (mainly indole units with multiple biological activities) are prepared by MCRs (Allen et al., 2017; Anand et al., 2017; Carbajales et al., 2017; Gribble, 2000). The unique indole backbone is considered to be the most widespread compound that is common in medical advances. Similarly, an indole is a substructure of many natural medical activities (Gribble, 2010). In addition, several indole compounds have attracted more

\section{${ }^{*}$ Corresponding Author}

Mohamed A. A. Radwan, Applied Organic Chemistry Department, National Research Center, Dokki, 12622, Egypt; National Research Centre, Cairo,Egypt.E-mail:m1radwan@yahoo.com consideration owing to their biological properties, such as their antimicrobial, anticancer, and antiviral activities (Bao et al., 2005; Endo et al., 2007; Sakemi and Sun, 1991; Yang et al., 2004). In such an indole, a framework, triazole (Duran et al., 2002; Gujjar et al., 2009; Holla et al., 2005; Sztanke et al., 2008) and pyrimidine (Kim et al., 2012; Selvaraj and Rajesh, 2016) ring, is well identified as the key structure of several therapeutic scaffolds as they display diverse bioactivities. Fused heterocycles are widely considered due to their share in the different steps of drug discovery, and they often function as basic central units in many therapeutic chemistry programs (Coxon et al., 2017; Taylor et al., 2014). Among them, the triazolopyrimidinone unit, a purine analog, is well known for displaying some biological activities, such as anti-inflammatory activity, ulcerogenic properties, serotonin antagonist, analgesic, antimicrobial, antifungal, cytotoxic, and antitumor activities (Boechat et al., 2012; Hafez et al., 2008; Huang et al., 2012; Lakamoska et al., 2009; Wang et al., 2017; Zhang et al., 2007; Zhao et al., 2007). Moreover, triazolopyrimidines have the greatest valuable construction base for the synthesis of bioactive drugs (Fig. 1) (Łakomska et al., 2013), which possess many pharmacological measures, such as antitumor (Marwaha et al., 2012), antimalarial (Luo et al., 2013), antimicrobial, (Abdel-Aziem et al., 2012), 
and anti-inflammatory activities (Khera et al., 2011), inhibition of the kinase insert domain-covering receptor (kill/death ratio kinase) (Ashour et al., 2013), and antifungal properties (Chen et al., 2008). They are known to show anticancer, anti-Alzheimer's, antihypertensive, leishmanicidal cardiac stimulant, antipyretic, potential herbicidal, and anti-HBV activities (Gujjar et al., 2009). The previous biological history of triazolopyrimidine is evident in Trapidil (Fischer, 2008) and Cevipabulin (El-Gendy et al., 2008). Recently, triazolopyrimidines have been realized to modify AChE inhibition, amyloid $\beta$-aggregation inhibition, anti-inflammation, and are noted as a probable anti-Alzheimer's agent (Kumar et al., 2016). Generally, heterocyclic compounds have many applications (Adole et al., 2019, 2020; Bisht et al., 2018; Chobe et al., 2014; Kamble et al., 2016). As an extension of our work regarding the direction on the synthesis of bioactive indolyl molecules (ElNezhawy et al., 2016, 2009a, 2009b; Fakhr et al., 2004, 2009;
Ghorab et al., 2008; Muhammad et al., 2019; Radwan and ElSherbiny, 2007; Radwan and Eman, 2009; Radwan et al., 2007; Radwan et al., 2009a, 2009b, 2020) (Fig. 2), we describe herein a multicomponent synthesis and antitumor estimation of the novel triazolopyrimidine-6-carbonitrile derivatives via the reaction of 3-aminotriazole, suitable aldehydes, and 3-cyanoacetyl indole.

\section{MATERIALS AND METHODS}

Chemicals were obtained from Merck and Sigma-Aldrich. Melting point $\left({ }^{\circ} \mathrm{C}\right)$ was measured on the XT-5 microscopic apparatus. $\mathrm{C}, \mathrm{H}$, and $\mathrm{N}$ analyses and infrared (IR) spectra, which were measured using an iS10 spectrometer $\left(v\right.$ in $\left.\mathrm{cm}^{-1}\right)$ using $\mathrm{KBr}$ disk, were carried out at Cairo University. MS (EI) $m / z$ analysis was carried out via a Thermo Scientific DCQII. ${ }^{1} \mathrm{H}$ and ${ }^{13} \mathrm{C}$ nuclear magnetic resonance (NMR) were carried out in dimethyl sulfoxide $\left(\mathrm{DMSO}_{-} \mathrm{d}_{6}\right)$ on a Bruker (400 MHz) Ascend - Magnets | Bruker spectrometer.

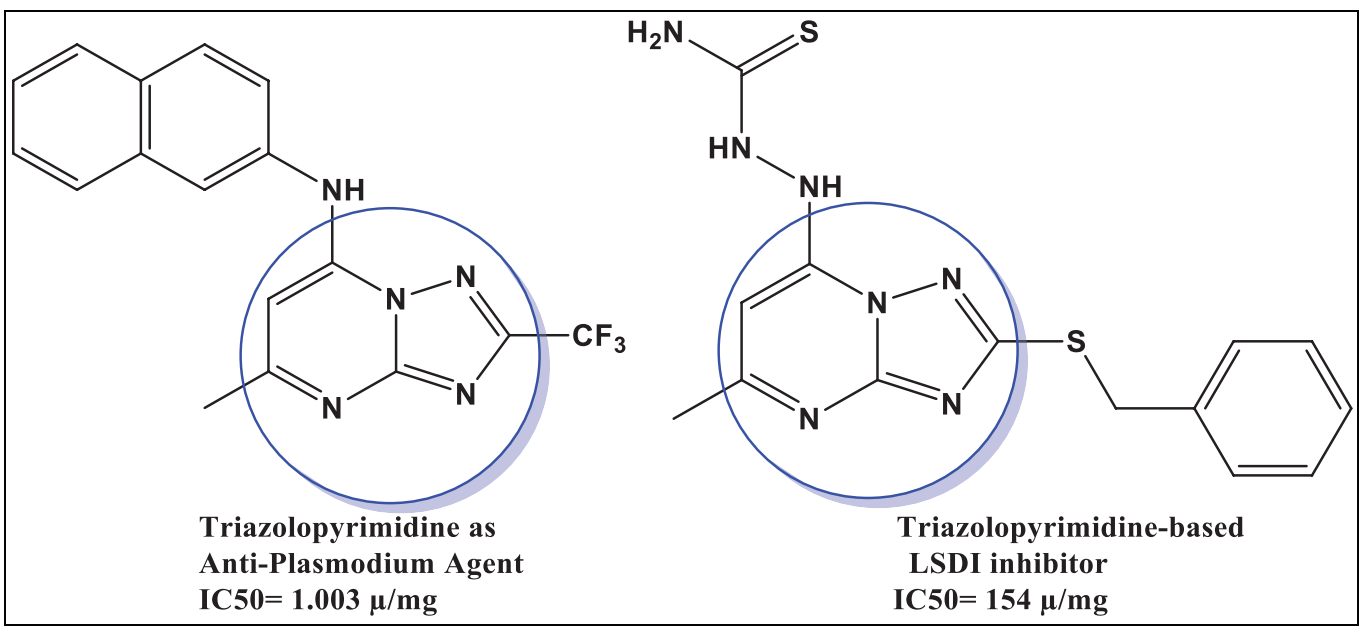

Figure 1. Biological activity of some of the triazolopyrimidine compounds.

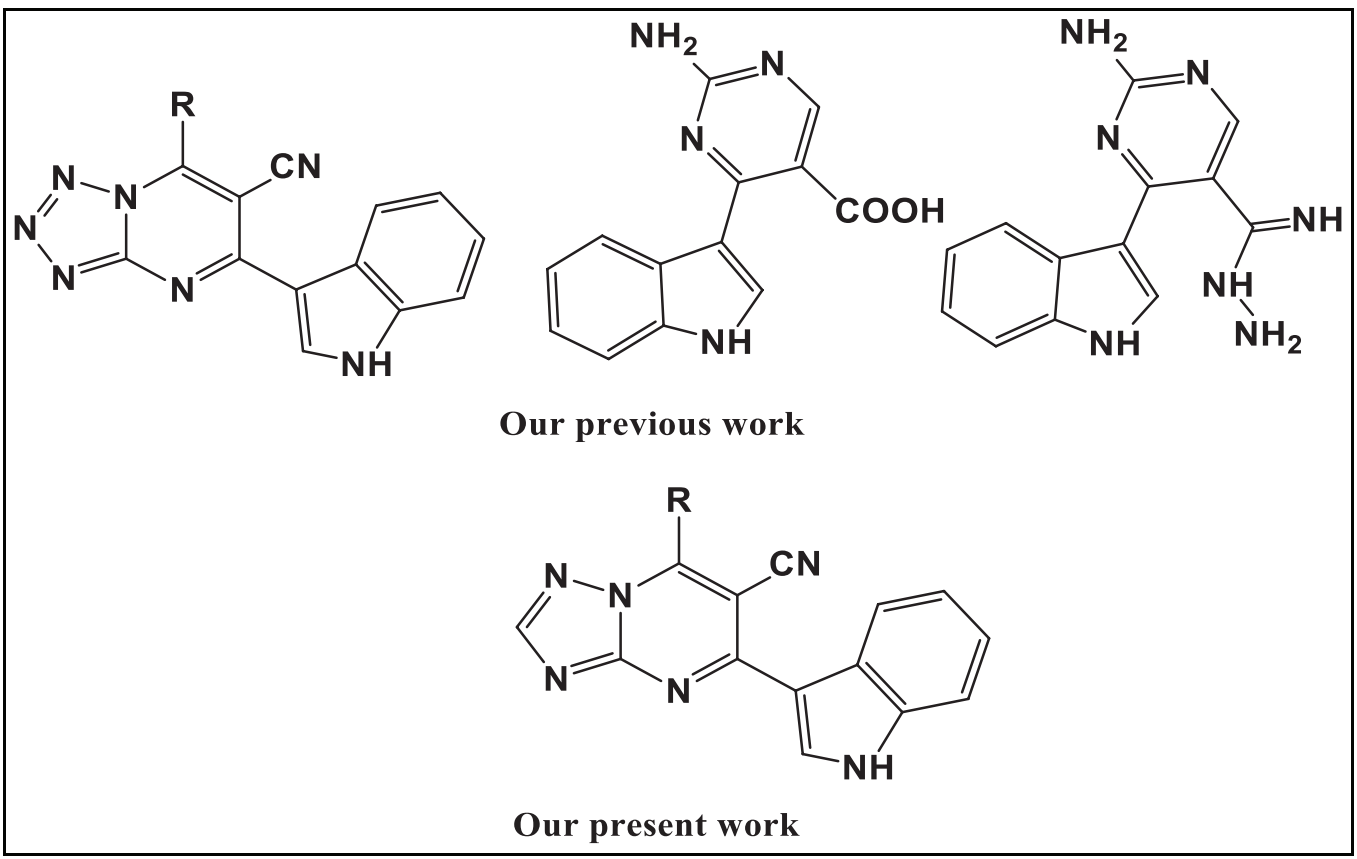

Figure 2. Some of our previous and present works bearing indole moiety. 
Synthesis of 7-substituted-5-(1H-indol-3-yl)-[1,2,4]triazolo [1,5-a]pyrimidine-6-carbonitrile 4a-i

\section{General method}

Triethylamine $(0.5 \mathrm{mmol})$ was added to a mixture of aldehydes (1 mmol), 3-amino-1,2,4-triazole (1 mmol), and 3 -cyanoacetyl-indole $(1 \mathrm{mmol})$ in dimethyl-formamide (DMF) $(5$ $\mathrm{ml}$ ), and heated at $120^{\circ} \mathrm{C}$ for about 10 hours (observed by thin layer chromatography). Then, the mixture was cooled and the precipitate was recrystallized from Ethanol/Dimethyl-Formamide (EtOH/DMF).

\section{7-(4-Chlorophenyl)-5-(1H-indol-3-yl)-[1,2,4]triazolo[1,5-a] pyrimidine-6-carbonitrile (4a)}

Yield $76 \% ; \mathrm{mp} 281^{\circ} \mathrm{C}-3^{\circ} \mathrm{C}$. IR $\left(\mathrm{KBr}, \mathrm{cm}^{-1}\right): 3,312(\mathrm{NH})$, 2,212 (CN). ${ }^{1} \mathrm{H}$ NMR (DMSO-d $)$ ) $\delta / p p m: ~ 7.23-7.27$ (m, 2H, indole H-5, H-6), 7.51-7.53 (dd, $J=1.1,8.4 \mathrm{~Hz}, 1 \mathrm{H}$, indole H-7), 7.63$7.64(\mathrm{~d}, J=7.6 \mathrm{~Hz}, 2 \mathrm{H}, \mathrm{Ph}), 8.03-8.04$ (d, $J=7.6 \mathrm{~Hz}, 2 \mathrm{H}, \mathrm{Ph}), 8.13$ (dd, $J=1.1,8.4 \mathrm{~Hz}, 1 \mathrm{H}$, indole $\mathrm{H} 4), 8.20$ (s, $1 \mathrm{H}$, triazole), 8.43 (s, 1H, indole-H2), 12.30 (brs, NH); ${ }^{13} \mathrm{C}$ NMR (DMSO-d $\left._{6}\right) \delta / p p m:$ 153.08, 149.44, 138.76, 136.72, 136.30, 131.34, 129.23, 126.04, $123.60,122.46,121.30,117.38,113.48,112.49,112.09$; MS (EI) $m / z \%$ : $371\left[\mathrm{M}^{+}+1\right]$. Anal. calcd. for $\mathrm{C}_{20} \mathrm{H}_{11} \mathrm{ClN}_{6}$ : C, 64.78; H, 2.99; N, 22.67. Found: C, 64.89; H, 2.91; N, 22.61.

\section{5-(1H-Indol-3-yl)-7-(4-nitrophenyl)-[1,2,4]triazolo[1,5-a] pyrimidine-6-carbonitrile (4b)}

Yield $76 \%$; $\mathrm{mp} 288^{\circ} \mathrm{C}-9^{\circ} \mathrm{C}$. IR $\left(\mathrm{KBr}, \mathrm{cm}^{-1}\right): 3,232$ (NH), 2,223 (CN). ${ }^{1} \mathrm{H}$ NMR (DMSO-d6) $\delta / \mathrm{ppm}:$ 7.23-7.28 (m, $2 \mathrm{H}$, indole $\mathrm{H} 5, \mathrm{H} 6), 7.52$ (dd, $J=1.1,8.6 \mathrm{~Hz}, 1 \mathrm{H}$, indole $\mathrm{H} 7$ ), 8.14 (dd, $J=1.1,8.4 \mathrm{~Hz}, 1 \mathrm{H}$, indole H4), 8.16-8.20 ( dd, $J=$ $1.1,8.1 \mathrm{~Hz}, 2 \mathrm{H}, \mathrm{Ph}), 8.31$ (s, $1 \mathrm{H}$, triazole), 8.36-8.38 (dd, $J=$ $1.1,8.1 \mathrm{~Hz}, 2 \mathrm{H}, \mathrm{Ph}), 8.47$ (s, 1H, indole-H2), 12.33 (brs, NH); ${ }^{13} \mathrm{C}$ NMR (DMSO-d6) $\delta / \mathrm{ppm}: 153.33,147.66,139.62,135.90$, $136.79,132.13,131.10,125.95,124.04,122.62,121.31,116.76$, 115.10, 113.42, 112.54; MS (EI) $m / z(\%) 383$ [M+2]. Anal. calcd. for $\mathrm{C}_{20} \mathrm{H}_{11} \mathrm{~N}_{7} \mathrm{O}_{2}$ : C, 62.99; H, 2.91; N, 25.71. Found: C, 63.12; H, $2.93 ; \mathrm{N}, 25.45$.

\section{7-(4-Bromophenyl)-5-(1H-indol-3-yl)-[1,2,4]triazolo[1,5-a] pyrimidine-6-carbonitrile (4c)}

Yield $74 \%$; mp $279^{\circ} \mathrm{C}-81^{\circ} \mathrm{C}$. IR $\left(\mathrm{KBr}, \mathrm{cm}^{-1}\right): 3,232$ (NH), 2,223 (CN). ${ }^{1} \mathrm{H}$ NMR (DMSO-d $)$ $\delta /$ ppm: 7.23-7.26 (m, $2 \mathrm{H}$, indole H5, H6), 7.50 (dd, $J=1.1,8.3 \mathrm{~Hz}, 1 \mathrm{H}$, indole $\mathrm{H} 7$ ), $7.62-7.64$ (dd, $J=7.8 \mathrm{~Hz}, 2 \mathrm{H}, \mathrm{Ph}$ ), 8.02-8.03 (dd, $J=7.8 \mathrm{~Hz}$, $2 \mathrm{H}, \mathrm{Ph}), 8.12$ (dd, $J=1.1,8.3 \mathrm{~Hz}, 1 \mathrm{H}$, indole $\mathrm{H} 4), 8.21(\mathrm{~s}, 1 \mathrm{H}$, triazole), 8.44 (s, 1H, indole-H2), 12.28 (brs, $\mathrm{NH}) ;{ }^{13} \mathrm{C} \mathrm{NMR}$ $\left(\mathrm{DMSO}_{6}\right.$ ) $\delta / \mathrm{ppm}: 151.72,147.12,137.74,135.30,132.18$, $132.00,131.64,126.02,125.85,123.61,122.45,121.32,117.40$, 112.51, 112.12; MS (EI) $m / z$ (\%) $414\left[\mathrm{M}^{+}, 4\right] ; 3,286$ (NH), 2,204 (CN). Anal. calcd. for $\mathrm{C}_{20} \mathrm{H}_{11} \mathrm{BrN}_{6}$ : C, 57.85; H, 2.67; N, 20.24. Found: C, 57.90; H, 2.63; N, 20.19.

\section{7-(2-Hydroxyphenyl)-5-(1H-indol-3-yl)-[1,2,4] triazolo[1,5-a] pyrimidine-6-carbonitrile (4d)}

Yield $67 \%$; $\mathrm{mp} 271^{\circ} \mathrm{C}-3^{\circ} \mathrm{C}$. IR $\left(\mathrm{KBr}, \mathrm{cm}^{-1}\right): 3,210-3,324$ (OH and NH), 2,210 (CN). ${ }^{1} \mathrm{H}$ NMR (DMSO-d $)$ ) $/$ ppm: 7.21-7.27 (m, 2H, indole H5, H6), 7.32-7.39 (m, 4H, Ph), 7.48 (dd, $J=1.1$,
8.1 Hz, 1H, indole H7), 7.96-7.99 (dd, 2H, dd, $J=1.1,8.1 \mathrm{~Hz}, 1 \mathrm{H}$, indole $\mathrm{H} 4), 8.23(\mathrm{~s}, 1 \mathrm{H}$, triazole), $8.41(\mathrm{~s}, 1 \mathrm{H}$, indole- $\mathrm{H} 2), 12.19(\mathrm{~s}$, $\mathrm{OH}), 12.24$ (s, NH); ${ }^{3} \mathrm{C}$ NMR (DMSO-d ${ }_{6}$ ) $/$ ppm: 155.12, 153.67, 148.36, 141.23, 137.87, 136.90, 135.41, 133.16, 131.27, 126.54, $123.69,122.74,121.77,117.90,113.56,112.61,112.13$; MS (EI) $m / z(\%) 352\left[\mathrm{M}^{+}\right]$. Anal. calcd. for $\mathrm{C}_{20} \mathrm{H}_{12} \mathrm{~N}_{6} \mathrm{O}: \mathrm{C}, 68.18 ; \mathrm{H}, 3.43$; N, 23.85. Found: C, 68.25; H, 3.21; N, 23.81.

\section{5-(1H-Indol-3-yl)-7-(2-nitrophenyl)-[1,2,4] triazolo[1,5-a] pyrimidine-6-carbonitrile (4e)}

Yield $70 \%$; mp $291^{\circ} \mathrm{C}-3^{\circ} \mathrm{C}$. IR $\left(\mathrm{KBr}, \mathrm{cm}^{-1}\right): 3,202(\mathrm{NH})$, 2,206 (CN). ${ }^{1} \mathrm{H}$ NMR (DMSO-d $)$ $\delta / \mathrm{ppm}: 7.29-7.36(\mathrm{~m}, 2 \mathrm{H}$, indole H5, H6), 7.47 (dd, $J=1.1,8.2 \mathrm{~Hz}, 1 \mathrm{H}$, indole H7), 7.73-7.78 (m, $2 \mathrm{H}, \mathrm{Ph}), 7.96-7.98(\mathrm{~m}, 2 \mathrm{H}, \mathrm{Ph}), 8.02-8.03(\mathrm{dd}, J=1.1,8.2 \mathrm{~Hz}$, $1 \mathrm{H}$, indole $\mathrm{H} 4), 8.24(\mathrm{~s}, 1 \mathrm{H}$, triazole), $8.40(\mathrm{~s}, 1 \mathrm{H}$, indole-H2),

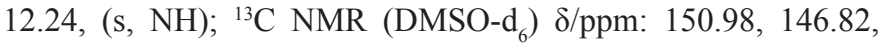
$145.66,138.65,137.96,135.92,135.31,132.36,128.22,127.02$, $124.63,123.47,122.31,118.37,114.49,112.11,111.95$. MS (EI) $m / z(\%) 384\left[\mathrm{M}^{+}+2\right]$. Anal. calcd. for $\mathrm{C}_{20} \mathrm{H}_{11} \mathrm{~N}_{7} \mathrm{O}_{2}: \mathrm{C}, 62.99 ; \mathrm{H}$, $2.91 ; \mathrm{N}, 25.71$. Found: C, 63.17; H, 2.90; N, 25.41.

\section{5-(1H-Indol-3-yl)-7-(thiophen-2-yl)-[1,2,4]triazolo[1,5-a] pyrimidine-6-carbonitrile (4f)}

Yield $64 \%$; mp $266^{\circ} \mathrm{C}-8^{\circ} \mathrm{C}$. IR $\left(\mathrm{KBr}, \mathrm{cm}^{-1}\right)$ : 3,245 (NH), 2,213 (CN). ${ }^{1} \mathrm{H}$ NMR (DMSO-d $)$ ) $/ \mathrm{ppm:} \mathrm{7.20-7.23}$ (m, 2H, thiophene), 7.31-7.32 (m, 2H, indole H5, H6), 7.46 (dd, $J$ $=1.1,8.4 \mathrm{~Hz}, 1 \mathrm{H}$, indole $\mathrm{H} 7), 7.53(\mathrm{~s}, 1 \mathrm{H}$, thiophene), 7.99-8.03 (dd, $J=1.1,8.4 \mathrm{~Hz}, 1 \mathrm{H}$, indole $\mathrm{H} 4), 8.26$ (s, $1 \mathrm{H}$, triazole), 8.45 (s, 1H, indole-H2), 12.28, (s, NH); ${ }^{13} \mathrm{C}$ NMR (DMSO-d $)$ ) $/ \mathrm{ppm}$ : $146.40,137.76,135.52,134.38,134.21,129.51,127.12124 .50$, $123.31,122.42,117.14,114.73,113.44,107.65$; MS (EI) $m / z(\%)$ $342\left[\mathrm{M}^{+}\right]$. Anal. calcd. for $\mathrm{C}_{18} \mathrm{H}_{10} \mathrm{~N}_{6} \mathrm{~S}: \mathrm{C}, 63.15 ; \mathrm{H}, 2.94 ; \mathrm{N}, 24.55$; S, 9.36. Found: C, 63.21; H, 2.91; N, 24.52; S, 9.34.

\section{7-(Furan-2-yl)-5-(1H-indol-3-yl)-[1,2,4]triazolo[1,5-a] pyrimidine-6-carbonitrile (4g)}

Yield $64 \%$; mp $269^{\circ} \mathrm{C}-71^{\circ} \mathrm{C}$. IR $\left(\mathrm{KBr}, \mathrm{cm}^{-1}\right): 3,232$ (NH), $2,214(\mathrm{CN}) .{ }^{1} \mathrm{H}$ NMR (DMSO-d $) \delta / p p m: ~ 7.11(\mathrm{~m}, 1 \mathrm{H}$, furan), 7.32-7.34 (m, 2H, indole $\mathrm{H} 5, \mathrm{H} 6), 7.47$ (dd, $J=1.1,8.5$ $\mathrm{Hz}, 1 \mathrm{H}$, indole $\mathrm{H} 7), 7.51(\mathrm{~m}, 1 \mathrm{H}$, furan), 7.98 ( $\mathrm{m}, 1 \mathrm{H}$, furan), 8.028.03 (dd, $J=1.1,8.5 \mathrm{~Hz}, 1 \mathrm{H}$, indole $\mathrm{H} 4), 8.22$ (s, $1 \mathrm{H}$, triazole), 8.43 (s, 1H, indole-H2), 12.17 (s, NH); $\left.{ }^{13} \mathrm{C} \mathrm{NMR} \mathrm{(DMSO-d}\right)$ ) $/$ ppm: 149.80, 147.64, 138.46, 136.12, 127.20, 124.50, 123.30, $121.32,120.41,118.74,115.01,114.64,113.44,106.72$. MS (EI) $m / z(\%) 326\left[\mathrm{M}^{+}\right]$. Anal. calcd. for $\mathrm{C}_{18} \mathrm{H}_{10} \mathrm{~N}_{6} \mathrm{O}: \mathrm{C}, 66.25 ; \mathrm{H}, 3.09$; $\mathrm{N}, 25.75$. Found $\mathrm{C}, 66.31 ; \mathrm{H}, 3.01 ; \mathrm{N}, 25.83$.

\section{5-(1H-Indol-3-yl)-7-(1H-pyrrol-2-yl)-[1,2,4]triazolo[1,5-a] pyrimidine-6-carbonitrile (4h)}

Yield $67 \%$; mp $258^{\circ} \mathrm{C}-61^{\circ} \mathrm{C}$. IR $\left(\mathrm{KBr}, \mathrm{cm}^{-1}\right): 3,221$

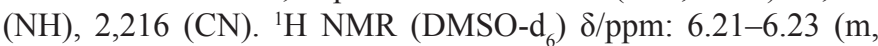
$1 \mathrm{H}$, pyrrole-H3), 6.51-6.52 (d, 1H, pyrrole-H4), 7.02-7.03 (d, $1 \mathrm{H}$, pyrrole-H2), 7.31-7.34 (m, 2H, indole H5, H6), 7.43 (dd, $J$ $=1.1,8.6 \mathrm{~Hz}, 1 \mathrm{H}$, indole H7), 8.01-8.02 (dd, $J=1.1,8.6 \mathrm{~Hz}, 1 \mathrm{H}$, indole $\mathrm{H} 4), 8.20(\mathrm{~s}, 1 \mathrm{H}$, triazole), $8.41(\mathrm{~s}, 1 \mathrm{H}$, indole- $\mathrm{H} 2), 11.64(\mathrm{~s}$,

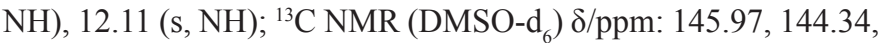
137.86, 136.12, 127.13, 124.43, 123.30, 123.08, 122.11, 118.06, 114.36, 113.88, 111.20, 105.01; MS (EI) $m / z(\%) 327\left[\mathrm{M}^{+}+2\right]$. 
Anal. calcd. for $\mathrm{C}_{18} \mathrm{H}_{11} \mathrm{~N}_{7}: \mathrm{C}, 66.45 ; \mathrm{H}, 3.41 ; \mathrm{N}, 30.14$. Found: $\mathrm{C}$, $66.53 ; \mathrm{H}, 3.37 ; \mathrm{N}, 30.12$.

\section{5,7-di(1H-Indol-3-yl)-[1,2,4]triazolo[1,5-a]pyrimidine-6- carbonitrile (4i)}

Yield $61 \%$; mp $296^{\circ} \mathrm{C}-8^{\circ} \mathrm{C}$. IR $\left(\mathrm{KBr}, \mathrm{cm}^{-1}\right)$ : $3,236-$ 3,265 (2NH), 2,206(CN). ${ }^{1} \mathrm{H}$ NMR (DMSO-d $\left.{ }_{6}\right) \delta / \mathrm{ppm}: 7.31-7.35$ (m, 4H, di-indole $\mathrm{H} 5, \mathrm{H} 6), 7.48$ (dd, $J=1.1,8.1 \mathrm{~Hz}, 2 \mathrm{H}$, di-indole H7), 8.01-8.02 (dd, $J=1.1,8.1 \mathrm{~Hz}, 2 \mathrm{H}$, di-indole H4), 8.18 (s, $1 \mathrm{H}$, triazole), $8.31,8.32(\mathrm{ss}, 2 \mathrm{H}$, indole- $\mathrm{H} 2), 12.21(\mathrm{~s}, \mathrm{NH}), 12.23$

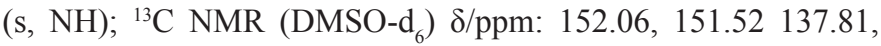
$137.74,135.31,132.33,131.10,128.24,127.03,124.95,124.61$, $123.47,122.31,118.39,114.47,112.23,111.16$; MS (EI) $\mathrm{m} / \mathrm{z}(\%)$ $375\left[\mathrm{M}^{+}\right]$. Anal. calcd. for $\mathrm{C}_{22} \mathrm{H}_{13} \mathrm{~N}_{7}: \mathrm{C}, 70.39 ; \mathrm{H}, 3.49 ; \mathrm{N}, 26.12$. Found: C, 70.45; H, 3.42; N, 26.10 .

\section{In vitro cell culture}

The human colorectal carcinoma (HCT-116) and human breast adenocarcinoma (MCF-7), (MDA-MB-231), and (A549) cell lines were acquired from the American Type Culture Collection (ATCC, Rockville, MD) and preserved in the DMEM-F12 medium which was complemented with $10 \%$ heat-inactivated fetal bovine serum, $100 \mathrm{U} / \mathrm{ml}$ penicillin, and $100 \mathrm{U} / \mathrm{ml}$ streptomycin. The cells were grown at $37^{\circ} \mathrm{C}$ in a moistened atmosphere of $5 \% \mathrm{CO}_{2}$.

\section{3-(4,5-Dimethylthiazol-2-yl)-2,5-Diphenyltetrazolium Bromide (MTT) antiproliferative assay}

The antiproliferative activity on HCT-116, MCF-7, MDA-MB-231, and A549 human cancer cells and retinal pigment ephitilial-1 (RPE-1) human normal cells was assessed by the MTT assay, which depends on the reduction of the tetrazolium salt by mitochondrial dehydrogenases in feasible cells (Ashraf et al., 2017; Emam et al., 2017; Eman et al., 2017). Cells were first distributed in a 96-well sterile microplate $\left(2 \times 10^{4}\right.$ cells $/$ well $)$ and incubated at $37^{\circ} \mathrm{C}$ in DMSO with diverse concentrations of each established compound or doxorubicin for 48 hours in a serum-free medium. After incubation, the media were carefully discarded, and $40 \mu \mathrm{l}$ of MTT $(2.5 \mathrm{mg} / \mathrm{ml})$ was added to individual wells and then incubated for an extra 4 hours. The purple formazan dye crystals were solubilized by adding $200 \mu 1$ of DMSO. The absorbance was measured at $570 \mathrm{~nm}$ via a SpectraMax Paradigm multimode microplate reader. The comparative cell viability was stated as the mean ratio of viable cells related to the unprocessed control cells. All trials were conducted in triplicate and repeated on three diverse days. The values were signified as mean $\pm \mathrm{SD}$. The efficacious doses for $50 \%$ of the cancerous cells population $\left(\mathrm{ED}_{50}\right)$ and their toxic doses in $50 \%$ of the noncancerous cells population were evaluated by Probit analysis by the Statistical Package for the Social Sciences (IBM Corp., Armonk, NY).

\section{RESULTS AND DISCUSSION}

\section{Chemistry}

The strategy in the presented work is the synthesis of a new series of triazolopyrimidine derivatives via an MCR of proper carboxaldehydes 1, 3-amino-1,2,4-triazole 2, and 3-indolyl-3oxopropanenitrile 3 (Scheme 1 and Scheme 2).

The MCR was carried out in the presence of different solvents and bases to check the effect on the rate of reaction and to find out the standard optimized reaction conditions

When the MCR was completed in ethanol without a catalyst, despite heating for 12 hours (Table 1, entry 1), there was no product formation.

Subsequently, we catalyzed a reaction by triethylamine in different solvents (Table 1, entries 1-6). Then, we studied the reactions in various basic conditions (Table 1, entries 7-12). The reaction results showed that organic bases gave good results, while the yield of the reaction in the presence of inorganic strong bases, like $\mathrm{KOH}$ and $\mathrm{NaOH}$, is not satisfactory. Surprisingly, $\mathrm{K}_{2} \mathrm{CO}_{3}$ did not furnish the product.In conclusion, the best condition for this reaction is to soak in DMF in 0.25 mol triethylamine for 10 hours at $120^{\circ} \mathrm{C}$ (Table 1 , entry 6 ).

As a result of the overhead reaction, a possible mechanism was proposed for the construction of triazolopyrimidine. First, triethylamine activated the nucleophilic reaction of 3-indolyl-3-oxopropanenitrile 3 via hydrogen bonding to excite carboxaldehyde 1 . The initiation of carboxaldehyde by H-bond enhances the electrophilicity of the carboxaldehyde and improves the building of a transitional A (Reddi et al., 2015). Intermediate $\mathbf{A}$ and 3-amino-1,2,4-triazole $\mathbf{2}$ then undergo Michael's reaction to form intermediate $\mathbf{B}$ via intramolecular cyclization reaction to form a $\mathrm{C}-\mathrm{N}$ bond. Subsequently, compound $\mathbf{4}$ was obtained by autoxidation (Scheme 3).

The structure of the newly synthesized compounds (4a-i) was identified via the interpretation of spectral studies and mass analysis (experimental units), e.g., the IR of compound $\mathbf{4 a}$

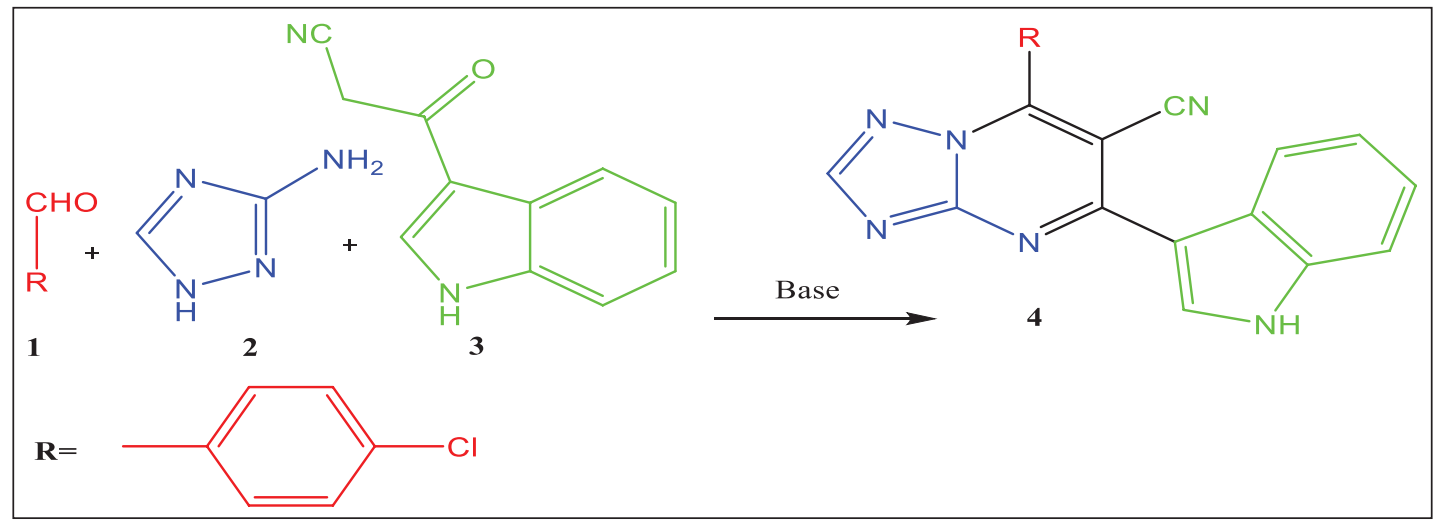

Scheme 1. Synthesis of triazolopyrimidine under different conditions of base, solvent, temperature, and time. 


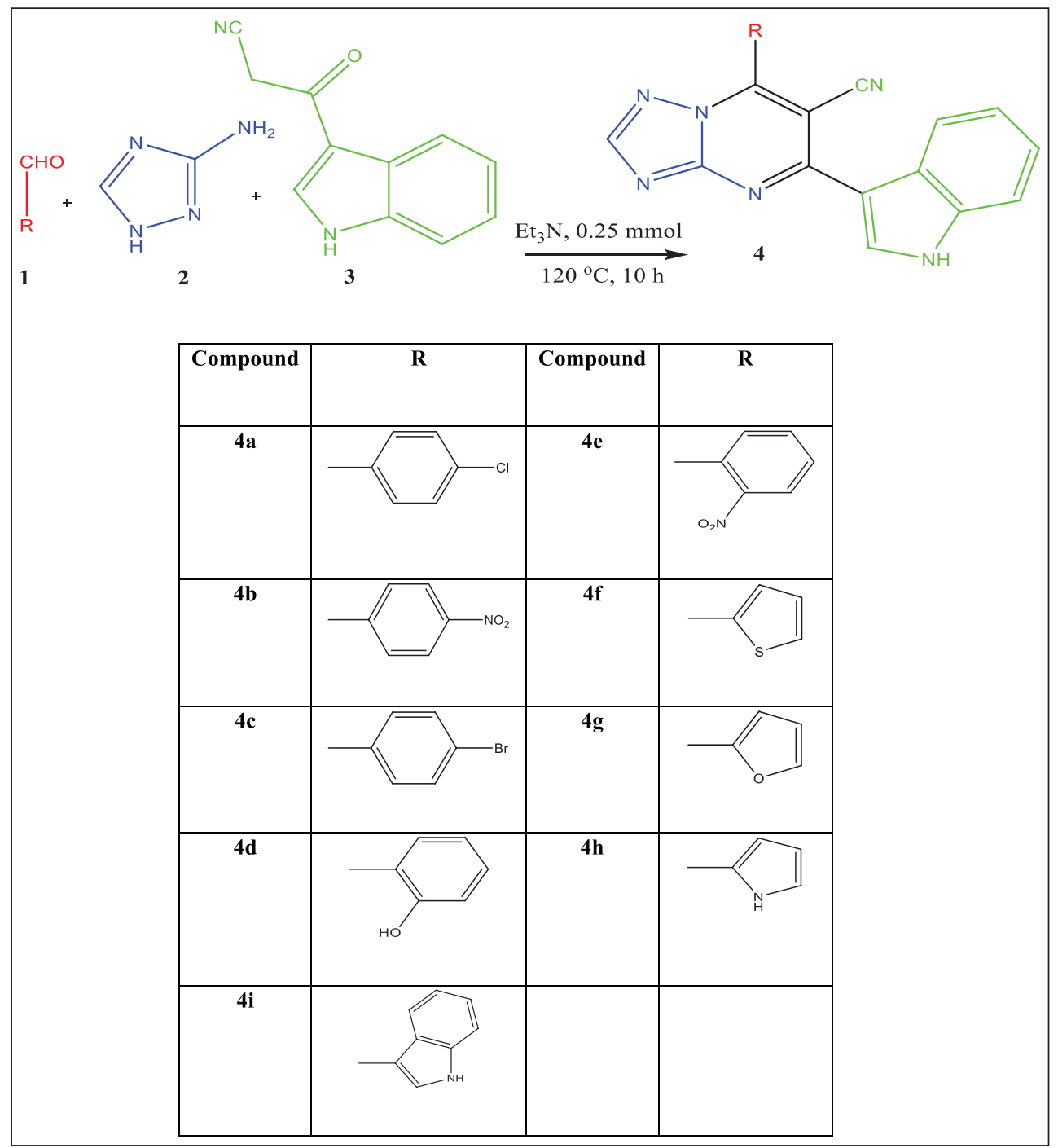

Scheme 2. Reaction conditions: aldehyde 1 ( $1 \mathrm{mmol}), 3$-amino-1,2,4-triazole 2 ( $1 \mathrm{mmol}), 3$-cyanoacetyl indole 3 (1 mmol), and $\mathrm{Et}_{3} \mathrm{~N}(0.25 \mathrm{mmol})$, in DMF at $120^{\circ} \mathrm{C}, 10$ hours.

Table 1. Optimization of the reaction conditions for the synthesis of triazolopyrimidine derivatives 4a.

\begin{tabular}{cccccc}
\hline Entry & Solvent & Alkali (mmol) & Temp. $\left({ }^{\circ} \mathbf{C}\right)$ & Time (hours) & Yield (\%) \\
\hline 1 & $\mathrm{EtOH}$ & 0 & 80 & 12 & 0 \\
2 & $\mathrm{EtOH}$ & $\mathrm{Et}_{3} \mathrm{~N}$ & 80 & 10 & Trace \\
3 & $\mathrm{CH}_{3} \mathrm{CN}$ & $\mathrm{Et}_{3} \mathrm{~N}$ & 80 & 10 & 17 \\
4 & $1,4-\mathrm{Dioxane}$ & $\mathrm{Et}_{3} \mathrm{~N}$ & 80 & 10 & 11 \\
5 & Toluene & $\mathrm{Et}_{3} \mathrm{~N}$ & 120 & 10 & 0 \\
6 & $\mathrm{DMF}$ & $\mathrm{Et}_{3} \mathrm{~N}$ & 120 & 10 & 79 \\
7 & $\mathrm{DMF}$ & Piperidine $(0.5)$ & 120 & 10 & 66 \\
8 & $\mathrm{DMF}$ & $\mathrm{DMAP}(0.2)$ & 120 & 10 & 33 \\
9 & $\mathrm{DMF}$ & Pyridine & 120 & 10 & 37 \\
10 & $\mathrm{CH}_{3} \mathrm{CN}$ & $\mathrm{KOH}$ & 80 & 8 & 20 \\
11 & $\mathrm{CH}_{3} \mathrm{CN}$ & $\mathrm{NaOH}$ & 80 & 8 & 24 \\
12 & $\mathrm{CH}_{3} \mathrm{CN}$ & $\mathrm{K} 2 \mathrm{CO}$ & 80 & 8 & Trace \\
\hline
\end{tabular}




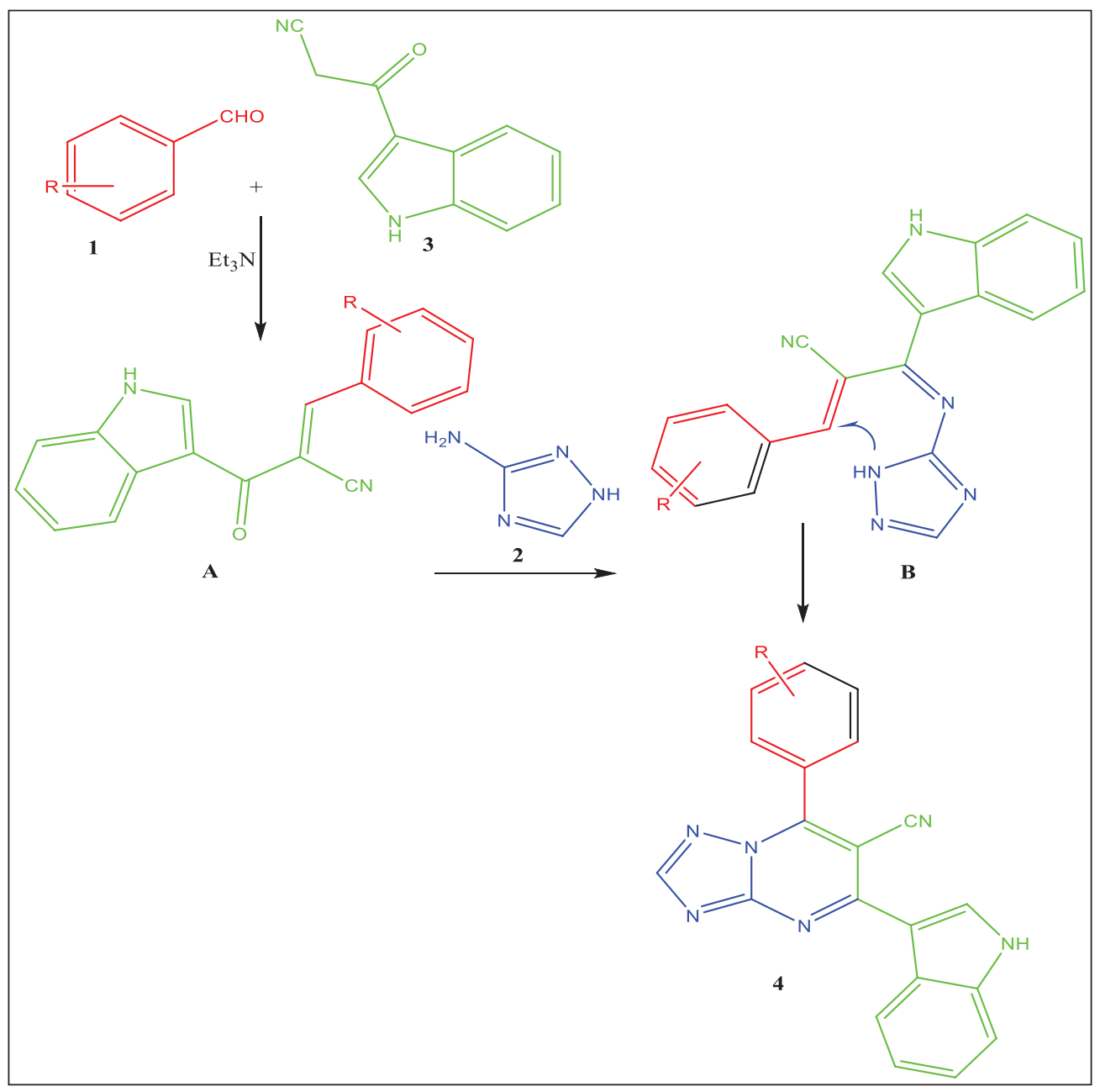

Scheme 3. Proposed mechanism of three-component reactions.

exposed bands at 3,312 and 2,212 $\mathrm{cm}^{-1}$ for the $\mathrm{NH}$ and cyano functions, respectively, along with the disappearance of $\mathrm{NH}_{2}$ and $\mathrm{C}=\mathrm{O}$ groups. Furthermore, ${ }^{1} \mathrm{H}$ NMR showed a broad peak (exchangeable $\mathrm{D}_{2} \mathrm{O}$ ) at $12.27 \mathrm{ppm}$ of the $-\mathrm{NH}$ group, a single peak at $8.20 \mathrm{ppm}$ of the triazole proton, and aromatic signals at 7.23$8.43 \mathrm{ppm}$. Also, ${ }^{13} \mathrm{C}$ NMR data and mass reinforced a proposed structure for $\mathbf{4 a}(\mathrm{m} / \mathrm{z} 370, \mathbf{M}+)$.

\section{Antiproliferative screening}

According to the revealed synthetic route, a series of the obtained triazolopyrimidines $(\mathbf{4 a}-\mathbf{4 i})$ was selected for further investigation of their antiproliferative activities in vitro on four human cancer types along with their cytotoxic effects on one nontumorous human healthy type RPE-1 by the MTT test. The proportion of live cells was evaluated and correlated with the control and reference drug doxorubicin. All compounds repressed the five human cell types (Figs. 3-7). In the HCT-116, Table 2 and Figure 3 demonstrate that compounds $\mathbf{4 a}$ and $\mathbf{4 h}$ had close antiproliferative effects, and the remaining compounds had significantly fewer antiproliferative activities than doxorubicin. While, in the MCF-7, compounds $4 \mathbf{i}$ and $4 \mathbf{h}$ had a more potent effect, compound $\mathbf{4 g}$ had a comparable activity and the rest of the compounds had less antiproliferative properties relative to doxorubicin (Fig. 4 and Table 2). For MDA-MB-231 human breast cancer, compounds $\mathbf{4 c}$ and $\mathbf{4 b}$ had a more potent effect; compounds $\mathbf{4 h}$ and $\mathbf{4 e}$ had equipotent effects; and compounds $\mathbf{4 d}$, $\mathbf{4 a}, \mathbf{4 g}, \mathbf{4 f}$, and $\mathbf{4 i}$ had significantly less antiproliferative effects related to doxorubicin (Fig. 5 and Table 2). For A549 cancer, compounds $\mathbf{4 d}, \mathbf{4 i}, \mathbf{4 e}, \mathbf{4 f}, \mathbf{4 g}$, and $\mathbf{4 h}$ had extra antiproliferative actions and compounds $\mathbf{4 b}, \mathbf{4 c}$, and $\mathbf{4 a}$ had insignificantly lesser antiproliferative effects than doxorubicin (Fig. 6 and Table 2). In the nontumorous human healthy normal cells (RPE-1), compounds $\mathbf{4 f}, \mathbf{4 g}$, and $\mathbf{4 e}$ were more toxic; three compounds $\mathbf{4 a}, \mathbf{4 i}$, and $\mathbf{4 d}$ had insignificant toxic effects; and three compounds $\mathbf{4 c}, \mathbf{4 b}$, and, 4h had significant toxic effects related to the reference drug.

These results indicated that all the prepared candidates are effective anticancer compounds in human lung cancer, except for compound 4a, which had significantly less activity; compound 4h had an effective antiproliferative activity on all cancerous types and had the least toxic effect on the noncancerous cells; and compound $4 \mathbf{i}$ had the best antiproliferative effect on both MCF-7 and A549 cancerous types, while having a weak antiproliferative effect on both HCT-116 and MDA-MB-231 cancerous types; compounds $\mathbf{4 i}, \mathbf{4 h}$, and $\mathbf{4 g}$ are efficient antiproliferative medicines on hormone-dependent contrary to the independent human breast cancer. 


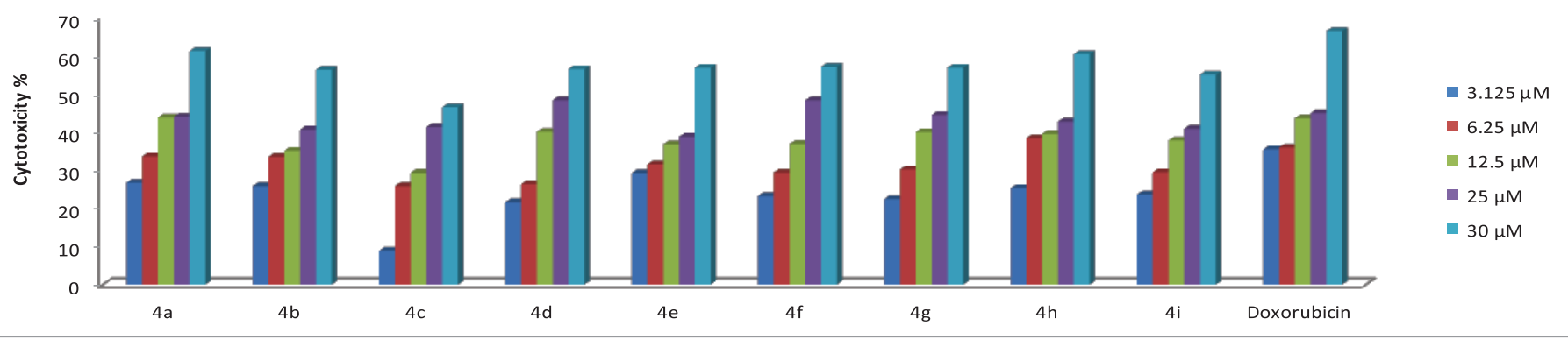

Figure 3. Dose-dependent antiproliferative effects of $\mathbf{4 a - 4 i}$ compounds on HCT-116 cancer cells via the MTT assay.

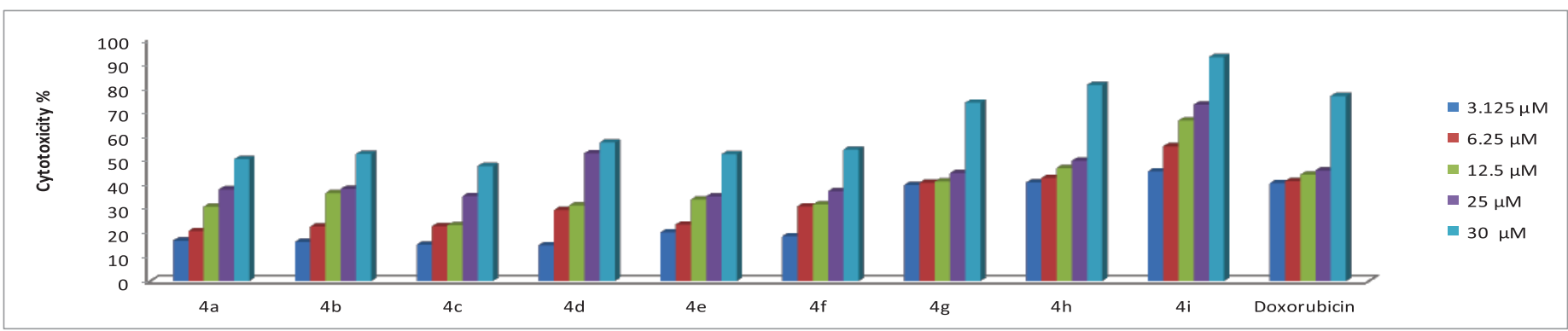

Figure 4. Dose-dependent antiproliferative effects of $\mathbf{4 a - 4 i}$ compounds on MCF-7 cancer cells via the MTT assay.

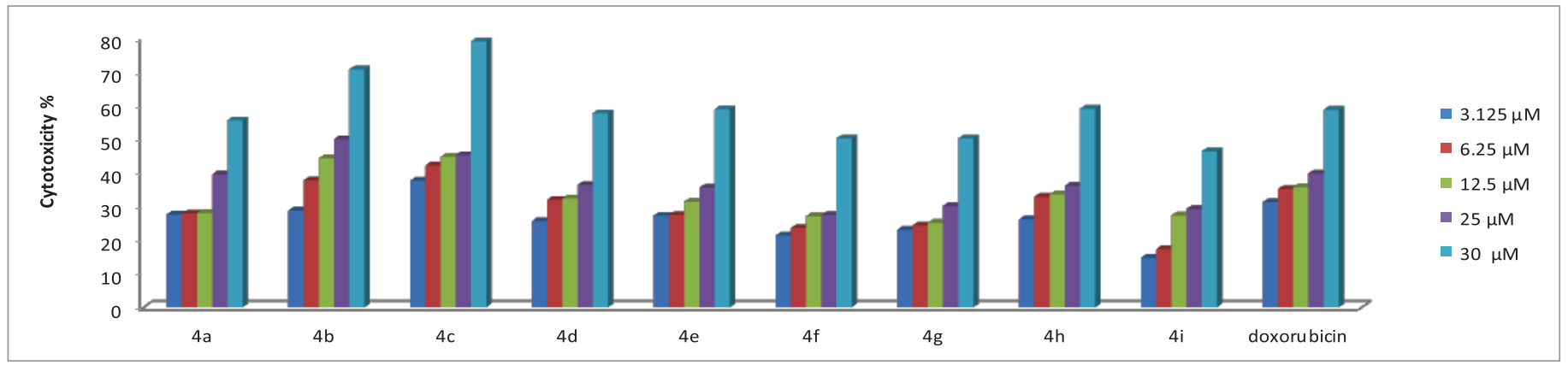

Figure 5. Dose-dependent antiproliferative effects of $\mathbf{4 a - 4 i}$ compounds on MDA-MB-231 cancer cells via the MTT assay.

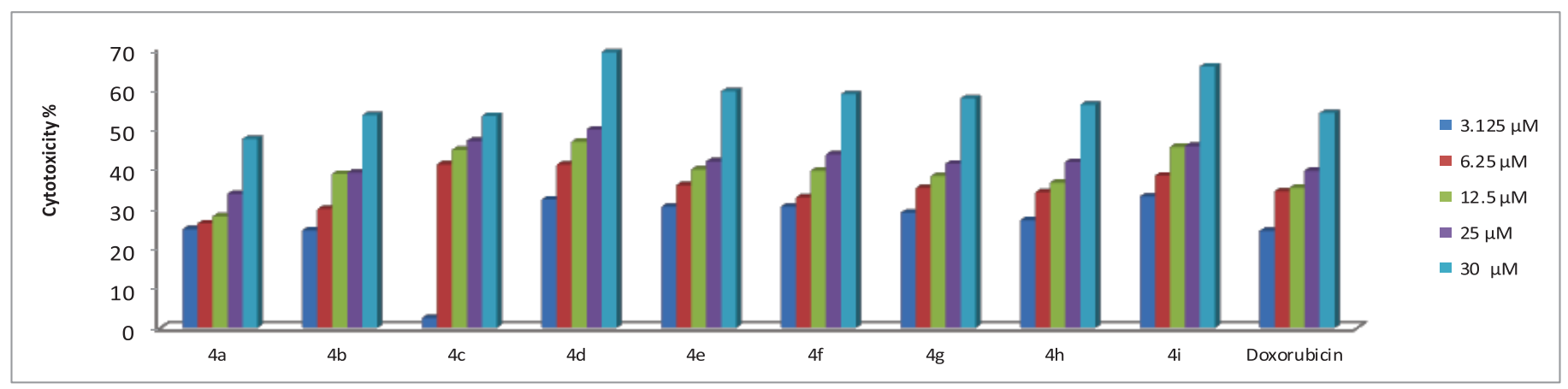

Figure 6. Dose-dependent antiproliferative effects of $\mathbf{4 a - 4 i}$ compounds on A549 cancer cells via the MTT assay. 


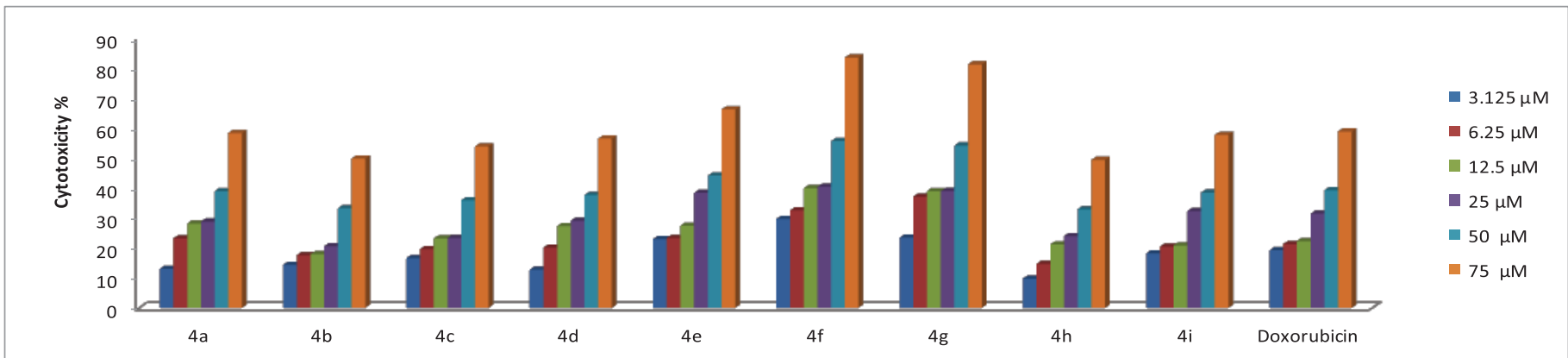

Figure 7. Dose-dependent toxic effects of $\mathbf{4 a - 4 i}$ compounds on RPE-1 human normal cells via the MTT assay.

Table 3. TI of the compounds' activities on the four cancer types relative to the normal cells according to the results in Table 2 .

\begin{tabular}{ccccc}
\hline \multirow{2}{*}{ Compounds } & \multicolumn{5}{c}{$\mathrm{TI}=\mathrm{ED}_{50} / \mathrm{TD}_{50}$} \\
\cline { 2 - 5 } & HCT-116 & MCF-7 & MDA-MB-231 & A549 \\
\hline $4 \mathrm{a}$ & 2.6 & 2.1 & 2.4 & 2.0 \\
$4 \mathrm{~b}$ & 2.8 & 2.6 & 3.6 & 2.7 \\
$4 \mathrm{c}$ & 2.2 & 2.2 & 3.8 & 2.5 \\
$4 \mathrm{~d}$ & 2.5 & 2.5 & 2.6 & 3.1 \\
$4 \mathrm{e}$ & 2.2 & 2.0 & 2.2 & 2.2 \\
$4 \mathrm{f}$ & 1.7 & 1.6 & 1.5 & 1.8 \\
$4 \mathrm{~g}$ & 1.8 & 2.3 & 1.5 & 1.8 \\
$4 \mathrm{~h}$ & 3.1 & 4.1 & 3.0 & 2.8 \\
$4 \mathrm{i}$ & 2.4 & 6.1 & 2.0 & 2.8 \\
Doxorubicin & 2.8 & 3.3 & 2.5 & 2.3 \\
\hline
\end{tabular}

Table 2. $\mathrm{EC}_{50}$ of the compounds on the four human cancer types and the $\mathrm{TD}_{50}$ on the noncancerous human normal cells via the MTT assay.

\begin{tabular}{cccccc}
\hline \multirow{2}{*}{ Compounds } & \multicolumn{2}{c}{$\mathrm{ED}_{50}(\mu \mathrm{M}) \pm \mathrm{SD}$} & \multicolumn{1}{c}{$\mathrm{TD}_{50}(\mu \mathrm{M}) \pm \mathrm{SD}^{-}$} \\
\cline { 2 - 6 } $\mathbf{4 a}$ & $\mathbf{H C T}-116$ & MCF-7 & MDA-MB-231 & A549 & RPE-1 \\
\hline $\mathbf{4 b}$ & $24.5 \pm 3.3$ & $29.8 \pm 4.5$ & $27.0 \pm 4.1$ & $31.7 \pm 4.5$ & $64.5 \pm 5.1$ \\
$\mathbf{4 c}$ & $32.3 \pm 4.2$ & $31.6 \pm 4.9$ & $18.3 \pm 3.5$ & $28.3 \pm 4.1$ & $75.5 \pm 5.5$ \\
$\mathbf{4 d}$ & $26.6 \pm 3.8$ & $26.3 \pm 3.9$ & $26.0 \pm 3.5$ & $21.8 \pm 3.4$ & $69.8 \pm 4.9$ \\
$\mathbf{4 e}$ & $26.4 \pm 3.9$ & $28.6 \pm 3.9$ & $25.5 \pm 4.2$ & $25.3 \pm 3.8$ & $56.8 \pm 4.5$ \\
$\mathbf{4 f}$ & $26.3 \pm 3.8$ & $27.7 \pm 4.2$ & $29.9 \pm 4.9$ & $25.6 \pm 3.9$ & $45.1 \pm 4.2$ \\
$\mathbf{4 g}$ & $26.4 \pm 4.1$ & $20.4 \pm 2.9$ & $29.9 \pm 4.7$ & $26.1 \pm 3.9$ & $46.3 \pm 4.1$ \\
$\mathbf{4 h}$ & $24.9 \pm 3.9$ & $18.5 \pm 2.3$ & $25.5 \pm 3.7$ & $26.9 \pm 4.1$ & $76.2 \pm 5.9$ \\
$\mathbf{4 i}$ & $27.3 \pm 3.9$ & $10.6 \pm 1.8$ & $32.4 \pm 4.9$ & $22.9 \pm 3.1$ & 65.5 .2 \\
Doxorubicin & $22.6 \pm 3.6$ & $19.6 \pm 2.9$ & $25.5 \pm 3.1$ & $27.9 \pm 4.1$ & $63.9 \pm 4.3$ \\
\hline
\end{tabular}

The therapeutic index (TI) of the compounds, which was calculated by dividing their efficacious dose for $50 \%$ of the cancerous cells population $\left(\mathrm{ED}_{50}\right)$ over their toxic dose in $50 \%$ of the noncancerous cells population, is presented in Table 3 (Hatem et al., 2019). From Table 3, it is obtained that the TI ranged from 1.7 to 3.1 compared to 2.8 for the reference drug on human colon cancer. In addition, TI ranged from 1.6 to 6.1 relative to 3.3 for the reference drug on the hormone-dependent human breast adenocarcinoma. While the TI ranged from 1.5 to 3.8 relative to 2.5 for the reference drug on the hormone-independent human breast adenocarcinoma. In addition, TI ranged from 1.8 to 3.1 relative to 2.3 for human lung cancer reference drugs. These results indicate that all synthetic compounds have the same efficacy and safety, or better in some compounds, than the standard drug doxorubicin.

\section{Structure activity relationships discussion}

In general, triazolopyrimidine derivatives have a function of promoting biological activity. In this work, all 
synthetic compounds have a built-in triazolopyrimidine unit with an important indole moiety at the 5-site. The compound $\mathbf{4 a}$ with 4-chlorophenyl at 7-position has the greatest antiproliferative activity against $\mathrm{HCT}-116\left(\mathrm{EC}_{50}=24.5 \mu \mathrm{M}\right)$, followed by compound 4h $\left(\mathrm{EC}_{50}=24.9\right)$, which comprises a pyrrole unit at 7-site. While with MCF-7 cells, $4 \mathbf{i}\left(\mathrm{EC}_{50}=10.6 \mu \mathrm{M}\right)$, which contains the biindole rings, compound $\mathbf{4 h}\left(\mathrm{EC}_{50}=18.5 \mu \mathrm{M}\right)$, which contains a pyrrole ring at 7-position, and compound $\mathbf{4 g}\left(\mathrm{EC}_{50}=20.4 \mu \mathrm{M}\right)$, which has a furan ring at 7-site are anticancer applicants on hormone-dependent instead of on hormone-independent human breast cancer. For, MDA-MB-231, compound $4 \mathbf{c}\left(\mathrm{EC}_{50}=18.3\right.$ $\mu \mathrm{M})$, which was substituted with 4-bromophenyl at position 7 , and compound $\mathbf{4 b}\left(\mathrm{EC}_{50}=21.3 \mu \mathrm{M}\right)$, which was substituted with 4-nitrophenyl at position 7, had more effect; compound $\mathbf{4 h}\left(\mathrm{EC}_{50}\right.$ $=25.5 \mu \mathrm{M}$ ), with pyrrole unit at the 7-site, and compound $4 \mathrm{e}$ $\left(\mathrm{EC}_{50}=25.5 \mu \mathrm{M}\right)$, substituted with 2-nitrophenyl at 7-position, had equipotent effects; compared to doxorubicin, compound $4 \mathbf{i}$ $\left(\mathrm{EC}_{50}=32.4 \mu \mathrm{M}\right)$, with the bi-indole rings, had a significantly lesser antiproliferative effect. In the A549 cancer type, compound 4d $\left(\mathrm{EC}_{50}=21.8 \mu \mathrm{M}\right)$, substituted with 2-nitrophenyl at 7-position, had more antiproliferative activity; compared to doxorubicin, compound $4 \mathbf{a}\left(\mathrm{EC}_{50}=31.7 \mu \mathrm{M}\right)$, substituted with 4-chlorophenyl at 7-position, had insignificantly lesser antiproliferative effects. Moreover, these results indicate that all synthetic compounds have the same efficacy and safety, or better in some compounds, than the standard drug doxorubicin.

\section{CONCLUSION}

The conventional three-component reactions have been used to construct a new series of triazolopyrimidine derivatives with built-in indole moiety. Compared to other traditional methods, this method is advanced in its cost-effectiveness, is easy to set-up, and results in high product quality. Antiproliferative activity of the new compounds has been examined toward four different human cancer cells and one human healthy cell line. Compounds $\mathbf{4 a}$ and $\mathbf{4 h}$ are active against the human colon cancer; all triazolopyrimidines are active toward MCF-7; $\mathbf{4 i}, \mathbf{4 h}$, and $\mathbf{4 g}$ are effective anticancer applicants on hormone-dependent instead of hormone-independent MCF-7. Consequently, it was found that the triazolopyrimidine derivatives could be studied for further biological investigation. Moreover, the multicomponent method is promising in the synthesis of many additional heterocyclic compounds.

\section{ACKNOWLEDGMENTS}

We express our appreciation to the National Research Centre and Qassim University for the services provided.

\section{CONFLICT OF INTEREST}

The authors declare that there is no conflict of interest.

\section{FINANCIAL SUPPORT AND SPONSORSHIP}

\section{None.}

\section{REFERENCES}

Abdel-Aziem A, El-Gendy MS, Abdelhamid AO. Synthesis and antimicrobial activities of pyrido [2, 3-d] pyrimidine, pyridotriazolopyrimidine, triazolopyrimidine, and pyrido [2, 3-d: 6, 5d'] dipyrimidine derivatives. Eur J Chem, 2012; 3:455-60.
Adole VA, More RA, Jagdale BS, Pawar TB, Chobe SS. Efficient synthesis, antibacterial, antifungal, antioxidant and cytotoxicity study of 2-(2-hydrazineyl) thiazole derivatives. ChemistrySelect, 2020; 5:2778-6.

Adole VA, Pawar TB, Koli PB, Jagdale BS. Exploration of catalytic performance of nano-La2O3 as an efficient catalyst for dihydropyrimidinone/thione synthesis and gas sensing. J Nanostruct Chem, 2019; 9:61-76.

Allen EE, Zhu C, Panek JS, Schaus SE. Multicomponent condensation reactions via ortho-quinone methides. Org Lett, 2017; 19:1878-81.

Anand D, Yadav PK, Patel OPS. Antileishmanial activity of pyrazolopyridine derivatives and their potential as an adjunct therapy with miltefosine. J Med Chem, 2017; 60:1041-59.

Ashour HM, Shaaban OG, Rizk OH, El-Ashmawy IM. Synthesis and biological evaluation of thieno $\left[2^{\prime}, 3^{\prime}: 4,5\right]$ pyrimido[1,2-b] $[1,2,4]$ triazines and thieno[2,3-d] $[1,2,4]$ triazolo[1,5-a]pyrimidines as antiinflammatory and analgesic agents. Eur J Med Chem, 2013; 62:341-51.

Ashraf SH, Mohamed FM, Hanem MA, Taghrid SH. Synthesis and antitumor activity of some new pyrazolo $[1,5$-a] pyrimidines. Chin Chem Lett, 2017; 28:388-93; doi:10.1016/j.cclet.2016.10.022

Bao B, Sun Q, Yao X, Hong J, Lee CO, Sim, CJ, Im KS, Jung $\mathrm{JH}$. Cytotoxic bisindole alkaloids from a marine sponge Spongosorites sp. J Nat Prod, 2005; 68:711-5.

Bisht GS, Pandey AM, Chaudhari MB, Agalave SG, Kanyal A, Karmodiya K, Gnanaprakasam B. Ru-Catalyzed dehydrogenative synthesis of antimalarial arylidene oxindoles. Org Biomol Chem, 2018; 16:7223-9?

Boechat N, Pinheiro LCS, Silva TS, Aguiar ACC, Carvalho AS, Bastos MM, Costa CCP, Pinheiro S, Pinto AC, Mendonça JS, Dutra KDB, Valverde AL, Santos-Filho OA, Ceravolo IP, Krettli AU. New trifluoromethyl triazolopyrimidines as anti-plasmodium falciparum agents. Molecules, 2012; 17:8285-302.

Carbajales C, Jun-ichi SJ, Marzaro G. Multicomponent assembly of the kinesin spindle protein inhibitor CPUYJ039 and analogues as antimitotic agents. ACS Comb Sci, 2017; 19:153-60.

Chen Q, Zhu XL, Jiang LL, Liu ZM, Yang GF. Synthesis, antifungal activity and CoMFA analysis of novel 1,2,4-triazolo[1,5-a] pyrimidine derivatives. Eur J Med Chem, 2008; 43:595-603.

Chobe SS, Adole VA, Deshmukh KP, Pawar TB, Jagdale BS. Poly (ethylene glycol)(PEG-400): a green approach towards the synthesis of novel pyrazolo [3, 4-d] pyrimidin-6-amines derivatives and their antimicrobial screening. Arch Appl Sci Res, 2014; 6:61-6.

Cioc RC, Ruijter E, Orru RVA. Multicomponent reactions: advanced tools for sustainable organic synthesis. Green Chem, 2014; 16:2958-75.

Coxon CR, Anscombe E, Harnor SJ, Martin MP, Carbain B, Golding BT, Hardcastle IR, Harlow LK, Korolchuk S, Matheson CJ, Newell DR, Noble MEM, Sivaprakasam M, Tudhope SJ, Turner DM, Wang LZ, Wedge SR, Wong C, Griffin RJ, Endicott JA, Cano C. Cyclin-dependent kinase (CDK) inhibitors: structure-activity relationships and insights into the CDK-2 selectivity of 6-Substituted 2-Arylaminopurines. J Med Chem, $2017 ; 1746-67$.

Dekamin MG, Eslami M, Maleki A. Potassium phthalimide- $N$ oxyl: a novel, efficient, and simple organocatalyst for the one-pot threecomponent synthesis of various 2 -amino- $4 \mathrm{H}$-chromene derivatives in water. Tetrahedron, 2013; 69:1074-85.

Duran A, Dogan HN, Rollas H. Synthesis and preliminary anticancer activity of new 1,4-Dihydro-3-(3-hydroxy-2-naphthyl)-4substituted-5H-1,2,4-triazoline-5-thiones. Farmaco, 2002; 57:559-64.

El-Gendy MMA, Shaaban M, Shaaban KA, El-Bondkly AM, Laatsch H. Essramycin: a first triazolopyrimidine antibiotic isolated from nature. J Antibiot, 2008; 61(3):149-57.

El-Nezhawy A, Eweas A, Radwan MA, El-Naggar T. Synthesis and molecular docking studies of novel 2-phenyl-4-substituted oxazole derivatives as potential anti-cancer agents. J Heterocycl Chem, 2016; $53: 271-9$ 
El-Nezhawy A, Gaballah S, Radwan MA. Studying the reactivity of (phthalazin-1(2H)-on-2-yl)methyl trichloroacetimidate towards different C- and O-nucleophiles. Tetrahedron Lett, 2009a; 50:6646-50.

El-Nezhawy A, Radwan MA, Gaballah S. Synthesis of chiral $\mathrm{N}-(2-(1-o x o p h t h a l a z i n-2(1 \mathrm{H})-y \mathrm{l})$ ethanoyl)- $\alpha$-amino acid derivatives as antitumor agents. Arkivoc, 2009b; 12:119-30.

Emam AN, Loutfy SA, Mostafa AA, Awad HM, Mohamed MB. Cyto-toxicity, biocompatibility and cellular response of carbon dotsplasmonic based nano-hybrids for bioimaging. RSC Adv, 2017; 7:2350214; doi:10.1039/C7RA01423F.

Eman MF, Wael AE, Ashraf MM, Walaa IE, Hanem MA. Synthesis and anticancer activity of new 1-thia-4-azaspiro[4.5]decane, their derived thiazolopyrimidine and 1,3,4-thiadiazole thioglycosides. Molecules, 2017; 22:170-3; doi:10.3390/molecules22010170

Endo T, Tsuda M, Fromont J, Jun'ichi K. Hyrtinadine A, a bisindole alkaloid from a marine sponge. J Nat Prod, 2007; 70:423-4.

Fakhr I, Hamdy N, Radwan MA, Ahmed Y. Synthesis of new bioactive benzothiophene derivatives. Egypt J Chem, 2004; 47:201-15.

Fakhr IM, Radwan MA, el-Batran S, Abd el-Salam OM, elShenawy SM. Synthesis and pharmacological evaluation of 2-substituted benzo[b]thiophenes as anti-inflammatory and analgesic agents. Eur J Med Chem, 2009; 44:1718-25.

Fischer G. Recent progress in 1,2,4-triazolo[1,5-a]pyrimidine chemistry. Adv Heterocycl Chem, 2008; 95:143-219.

Ghorab M, Radwan MA, Taha N, Amin N, Shehab M, Faker I. Dapson in heterocyclic chemistry, part II: antimicrobial and antitumor activities of some novel sulfone biscompounds containing biologically active thioureido, carbamothioate, quinazoline, imidazolidine, and thiazole moieties. Phosphorus Sulfur Silicon Relat Elem, 2008; 183:2906-17.

Gribble GW. Heterocyclic scaffolds II: reactions and applications of indoles. Springer, Berlin, Germany,

Gribble GW. Recent developments in indole ring synthesismethodology and applications. J Chem Soc Perkin 1, 2000; 7:1045-75.

Gujjar R, Marwaha A, White J, White L, Creason S, Shackleford DM, Baldwin J, Charman WN, Buckner FS, Charman S, Rathod PK, Phillips MA. Identification of a metabolically stable triazolopyrimidine based dihydroorotate dehydrogenase inhibitor with antimalarial activity in mice. J Med Chem, 2009; 52:1864-72.

Hafez HN, Abbas H-AS, El-Gazzar A-RBA. Synthesis and evaluation of analgesic, anti-inflammatory and ulcerogenic activities of some triazolo- and 2-pyrazolyl-pyrido[2,3-d]-pyrimidines. Acta Pharm, 2008; 58:359-78.

Hatem AA, Hanem MA, Mohamed M, Fahd AN, Ali S, Alqahtani A, Ahmed M, Rashad AS. Synthesis and biological evaluation of 4-(1H-1,2,4- triazol-1-yl)benzoic acid hybrids as anticancer agents. RSC Adv, 2019; 9:19065-74; doi:10.1039/c9ra03151k

Holla BS, Mahalinga M, Karthikeyen MS, Poojary B, Akberali PM, Kumari NS. Synthesis, characterization and antimicrobial activity of some substituted 1,2,3-triazoles. Eur J Med Chem, 2005; 40:1173-8.

Huang LH, Zheng YF, Lu YZ, Song CJ, Wang YG, Yu B, HongLiu M. Synthesis and biological evaluation of novel steroidal[17,16-d] $[1,2,4]$ triazolo[1,5- a]pyrimidines. Steroids, 2012; 77:710-5.

Kamble RD, Meshram RJ, Hese SV, More RA, Kamble SS, Gacche RN, Dawane BS. Synthesis and in silico investigation of thiazoles bearing pyrazoles derivatives as anti-inflammatory agents. Comput Biol Chem, 2016; 61:86-96.

Khera MJ, Cliffe IA, Marthur T, Prakash O. Synthesis and in vitro activity of novel 1,2,4-triazolo[4,3-a]pyrimidine oxazolidinone antibacterial agents. Bioorg Med Chem Lett, 2011; 21:2887-9.

Kim TW, Yoo BW, Lee JK, Kim JH, Lee K, Chi YH, Lee JY. Synthesis and antihypertensive activity of pyrimidin-4(3H)-one derivatives as losartan analogue for new angiotensin II receptor type 1 (AT1) antagonists. Bioorg Med Chem Lett, 2012; 22:1649-54.

Kumar J, Meena P, Singh A, Jameel E, Maqbool M, Mobashir M, Shandilya A, Tiwari M, Hoda N, Jayaram B. Synthesis and screening of triazolopyrimidine scaffold as multi-functional agents for Alzheimer's disease therapies. Eur J Med Chem, 2016; 119:260-77; doi:10.1016/j. ejmech.2016.04.053

Lakamoska I. Molecular structure and antitumor activity of platinum(II) complexes containing purine analogs. Inorg Chim Acta Rev, 2009; 362:669-81.

Łakomska I, Fandzloch M, Muziol T, Lis T, Jezierska J. Synthesis, characterization and antitumor properties of two highly cytotoxic ruthenium(III) complexes with bulky triazolopyrimidine ligands. Dalton Trans, 2013; 42:6219-26.

Liu C, Zhou L, Jiang D, Gu Y. Multicomponent reactions of aldo-X bifunctional reagent $\alpha$-oxoketene dithioacetals and indoles or amines: divergent synthesis of dihydrocoumarins, quinolines, furans, and pyrroles. Asian J Org Chem, 2016; 5:367-72.

Luo Y, Zhang S, Liu ZJ, Chen W, Fu J, Zeng Q-F, Zhu H-L. Synthesis and antimicrobical evaluation of a novel class of 1,3,4-thiadiazole: derivatives bearing 1,2,4-triazolo[1,5-a]pyrimidine moiety. Eur J Med Chem, 2013; 64:54-61.

Marwaha A, White J, El Mazouni F, Creason S, Kokkonda S, Buckner F, Rathod P. Bioisosteric transformations and permutations in the triazolopyrimidine scaffold to identify the minimum pharmacophore required for inhibitory activity against plasmodium falciparum dihydroorotate dehydrogenase. J Med Chem, 2012; 55:7425-37.

Muhammad Z, Radwan MA, Farghaly T, Gaber H, Elaasser M. Synthesis and antitumor activity of novel[1,2,4,5]tetrazepino[6,7-b]indole derivatives: marine natural product hyrtioreticuline $\mathrm{C}$ and $\mathrm{D}$ analogues. Mini Rev Med Chem, 2019; 19:79-86.

Peng J, Gao Y, Zhu C, Liu B, Gao Y, Hu M, Wu W, Jiang H. Synthesis of polysubstituted 3-amino pyrroles via palladium-catalyzed multicomponent reaction. J Org Chem, 2017; 82:3581-88.

Radwan MA, Abbas E. Synthesis of some pyridine, thiopyrimidine, and isoxazoline derivatives based on the pyrrole moiety. Monatsh Chem, 2009; 140:229-33.

Radwan MA, Alminderej FM, Awad HM. One-pot multicomponent synthesis and cytotoxic evaluation of novel 7-substituted5-(1H-indol-3-yl)tetrazolo[1,5-a]pyrimidine-6-carbonitrile. Molecules, 2020; 25:255; doi:10.3390/molecules25020255.

Radwan MA, El-Sherbiny M. Synthesis and antitumor activity of indolylpyrimidines: marine natural product meridianin D analogues Bioorg Med Chem, 2007; 15:1206-11.

Radwan MA, Ragab EA, Sabry NM, El-Shenawy SM. Synthesis and biological evaluation of new 3 -substituted indole derivatives as potential anti-inflammatory and analgesic agents. Bioorg Med Chem, 2007; 15:3832-41.

Radwan MA, Ragab EA, Shaaban MR, El-Nezhawy AO Application of (2Z)-3-dimethylamino-2-(1H-indole-3-carbonyl) acrylonitrile in the synthesis of novel 3-heteroarylindoles: condensed meridianine analogs. ARKIVOC, 2009a; 2009(7):281-91.

Radwan MAA, Shehab M, El-Shenawy S. Synthesis and biological evaluation of 5 -substituted benzo[b]thiophene derivatives as anti-inflammatory agents. Monatsh Chem, 2009b; 140:445-50.

Ravichandiran P, Lai B, Gu Y. Aldo-X bifunctional building blocks for the synthesis of heterocycles. Chem Rec, 2017; 17:142-83.

Reddi MNK, Park H, Lee HR, Suh H, Kim I. Efficient, solventfree, multi-component method for organic-base-catalyzed synthesis of $\beta$-phosphonomalonates. ACS Comb Sci, 2015; 17:691-97; doi:10.1021/ acscombsci.5b00109

Rotstein BH, Zaretsky S, Rai V, Yudi AK. Small heterocycles in multicomponent reactions. Chem Rev, 2014; 114:8323-59.

Sakemi S, Sun HH. Nortopsentins A, B, and C. Cytotoxic and antifungal imidazolediylbis[indoles] from the sponge Spongosorites ruetzleri. J Org Chem, 1991; 56:4304-7.

Selvaraj MR, Rajesh S. Synthetic chemistry of pyrimidines and fused pyrimidines: a review. Syn Commun, 2016; 46:645-72.

Sztanke K, Tuzimski T, Rzymowska J. Synthesis, determination of the lipophilicity, anticancer and antimicrobial properties of some fused 1,2,4-triazole derivatives. Eur J Med Chem, 2008; 43:404-19.

Taylor RD, MacCoss M, Lawson ADG. Rings in drugs, Miniperspective. J Med Chem, 2014; 57(14):5845-59. 
Wang S, Zhao LJ, Zheng YC, Shen DD, Miao EF, Qiao XP, Zhao LJ, Liu Y, Huang R, Yu B, Liu HM. Design, synthesis and biological evaluation of $[1,2,4]$ triazolo[1,5-a]pyrimidines as potent lysine specific demethylase 1 (LSD1/KDM1A) inhibitors. Eur J Med Chem, 2017; 125:940-51.

Yang CG, Huang H, Jiang B. Progress in studies of novel marine bis (indole) alkaloids. Curr Org Chem, 2004; 8:1691-720.

Zhang N, Ayral-Kaloustian S, Nguyen T, Afragola J, Hernandez R, Lucas J, Gibbons J, Beyer C. Synthesis and SAR of [1,2,4]Triazolo[1,5-a] pyrimidines, a class of anticancer agents with a unique mechanism of tubulin inhibition. J Med Chem, 2007; 50:319-27.
Zhao XL, Zhao YF, Guo SC, Song HS, Wang D, Gong P. Synthesis and antitumor activities of novel $[1,2,4]$ triazolo $[1,5-\mathrm{a}]$ pyrimidines. Molecules, 2007; 12:1136-46.

How to cite this article:

Radwan M, Alminderej F, Tolan H, Awad H. One-pot threecomponent synthesis of new triazolopyrimidine derivatives bearing indole moiety as antiproliferative agents. J Appl Pharm Sci, 2020; 10(09):012-022. 